$\begin{array}{ll}\text { Research Square } & \begin{array}{l}\text { Preprints are preliminary reports that have not undergone peer review. } \\ \text { They should not be considered conclusive, used to inform clinical practice, } \\ \text { or referenced by the media as validated information. }\end{array}\end{array}$

\title{
Extensive study on the impact of joint inclinations on the earth pressure in rock ground
}

Solomon Adedokun ( $\nabla$ siadedokun@unilag.edu.ng )

University of Lagos https://orcid.org/0000-0001-6347-8202

M. Son

Daegu University

Original Paper

Keywords: Joint inclinations, Rock types, Excavation, Retaining structure, Earth pressure, Rock-structure interaction

Posted Date: February 3rd, 2021

DOI: https://doi.org/10.21203/rs.3.rs-190601/v1

License: @ (i) This work is licensed under a Creative Commons Attribution 4.0 International License. Read Full License 


\section{Abstract}

The impact of different joint inclinations on the earth pressure was extensively carried out in this study, using Universal Distinct Element Code (UDEC) which is based on discrete element method. Numerical parametric investigations, which considered varying joint inclinations and rock types, were conducted after the numerical method had been verified through a physical model test. The joint angles considered ranged from $0^{\circ}$ to $90^{\circ}$ in the interval of $5^{\circ}$ and the rock types are hard, slightly and moderately weathered rocks. The results of the analyses were subjected to statistical analysis using analysis of variance (ANOVA) at $5 \%$ level of significance, and compared with empirical earth pressure envelope for sand ground. The comparisons showed that earth pressures in rock ground are substantially varied from those in sand ground. The result of ANOVA revealed that joint inclinations have statistically significant effect on magnitude of the earth pressure, and practitioners should consider this factor while designing retaining structure in rock masses.

\section{Introduction}

Several researches have investigated the earth pressure induced on the retaining structures through experimental, analytical and numerical studies (Terzaghi, 1934; 1936; Peck, 1969; Tschebotarioff, 1973; Lambe and Whitman, 1978; Potts and Foure, 1986; Wong et al., 1997; Haashash and Whittle, 2002; Worden and Achmus, 2013). Most of these studies mainly focused on soil grounds. The apparent empirical earth pressure envelopes proposed by Peck (1969) and Tschebotarioff (1973) are frequently used in practice for the design of the retaining structures installed in sand and clay soils (Fig. 1). Also, some works have assessed earth pressures induced on the retention walls in ground with multiple layers of soils and rocks (Lee and Jeon, 1993; Hong and Yoon, 1995; Jeong and Kim, 1997; Yoo, 2001; Gan et al., 2017; Zeng et al., 2018; Jeon and Lee, 2018; Fu et al., 2019). But these assessments only compared the earth pressures measured in multi-layered soils with the earth pressure proposed by Peck while the influence of varying properties of joint (inclinations, orientations, spacing, shear conditions, cohesive strengths, number of joint sets etc) were not considered. Since the previous researches (Peck, 1969; Tschebotarioff, 1973; Wong et al., 1997; Haashash and Whittle, 2002; Worden and Achmus, 2013) are mostly hinged on earth pressure assessments from soil grounds, it is not clear if the results of these researches can be used for rock strata. Accordingly, it is hard to find researches that have investigated earth pressures on the excavation walls installed rock ground with systematic joints. In the same way, Lee (2001 and 2004) suggested that the systematic study of the earth pressure magnitude and distribution on the retaining structures installed in rock masses are urgently required to investigate the impact of joint characteristics on earth pressure.

Rock has frequent joints, which characteristics varied significantly according to formation and weather conditions (Lee, 2001; Son and Adedokun, 2014a \& b). Because joint characteristics affect to a greater extent the overall behaviour of the rock mass, it is important to consider its effects when assessing earth pressure on the retaining structures in rock masses. However, some researches had recently assessed earth pressures on the excavation walls in rock masses with systematic joints (Son, 2013; Son and Park, 2014; Son and Adedokun, 2015; 2016; 2017) and reported that earth pressures are larger for rock ground compared to soil ground when rocks and joints are under poor conditions like joint sliding and weathered rock conditions. In contrast, earth pressures are smaller than the ones in soil ground when the rock strata are under good and fair conditions.

Therefore, this study presents an extensive study to the previous one (Son and Adedokun, 2015) on the effect of joint inclinations on earth pressures in rock masses, and its findings are expected to provide a better understanding of the impact of joint inclinations and rock types on earth pressure against the retaining structures installed in rock masses.

\section{Numerical Studies}

The numerical method used in this study has been verified with the numerical test of physical model test presented in the previous study by Son and Park (2014), which is also presented in Figure 2. This numerical method was conducted to extensively investigate the impact of joint inclinations (0-90 $)$ under different rock types on earth pressure against the excavation wall installed in rock mass. The angles of joint were measured from the horizontal plane in the counter clockwise direction, and the spacing of the joints assumed to be $1 \mathrm{~m}$ (with one joint set). Table 1 presents the wall and rock characteristics used in the analyses. The characteristics of the rocks were determined using some data published by Bienniawski (1976), Hoek and Brown (1988), and Goodman (1989). The Rock Mass Rating (RMR) for hard rock with good joint conditions and $1 \mathrm{~m}$ joint spacing was calculated in line with Bieniawski's (1989) method. The elastic modulus of the rock mass $E_{m}$ was then determined from the equation $E_{m}=2 R M R-100$ proposed by Bienniawski (1976). This value was used to compute the joint normal and shear stiffness for the numerical studies as shown in equations 1 and 2, respectively.

$$
\begin{aligned}
& \mathrm{k}_{\mathrm{n}}=\frac{\mathrm{E}_{\mathrm{m}} \mathrm{E}_{\mathrm{r}}}{\mathrm{s}\left(\mathrm{E}_{\mathrm{r}}-\mathrm{E}_{\mathrm{m}}\right)} \\
& \mathrm{k}_{\mathrm{s}}=\frac{\mathrm{G}_{\mathrm{m}} \mathrm{G}_{\mathrm{r}}}{\mathrm{s}\left(\mathrm{G}_{\mathrm{r}}-\mathrm{G}_{\mathrm{m}}\right)}
\end{aligned}
$$

Where $k_{n}=$ joint normal stiffness, $k_{s}=$ joint shear stiffness, $E_{m}$ is the rock mass elastic modulus, $G_{m}$ represents the shear modulus of the rock mass, $E_{r}$ is the elastic modulus of the intact rock, $G_{r}$ is the shear modulus of the intact rock and s represents the joint spacing.

The rock mass elastic moduli for slightly and moderately weathered rocks were determined by reducing the rock mass elastic modulus for hard rock by factor of 10 and 100 respectively. The joint normal and shear stiffness of this rock were then computed using the same procedures discussed above. Son and Yoon (2011) gave the detailed explanations for the assessment of these properties. The strut axial stiffness used for the numerical test was estimated using equation 3 . 


\section{$\mathrm{K}_{\text {sup }}=\frac{\mathrm{EA}}{\mathrm{L} \times \mathrm{Space}} \cos \theta$}

Where, $K_{\text {sup }}=$ strut axial stiffness, $A=$ cross sectional area of a strut $(300 \times 300 \times 10 \times 15 \mathrm{~mm} \mathrm{H}$-section), $E=$ elastic modulus of strut, $L=$ half of the strut length, Space $=$ strut horizontal spacing, $=$ the installation angle of strut (zero in horizontal installation).

Table 1. The properties of the wall, rocks, joints and interfaces used in the analyses

\begin{tabular}{|c|c|c|c|c|c|c|c|c|c|c|c|c|c|c|}
\hline \multirow{3}{*}{ Rock type } & \multirow{3}{*}{ 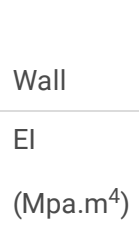 } & \multicolumn{9}{|c|}{ Rock and Joint } & \multirow{2}{*}{\multicolumn{4}{|c|}{ Rock-Wall interface }} \\
\hline & & \multicolumn{3}{|l|}{ Rock } & \multicolumn{6}{|l|}{ Joint } & & & & \\
\hline & & $\begin{array}{l}\mathrm{E}_{\mathrm{r}} \\
(\mathrm{MPa})\end{array}$ & $\mathrm{n}$ & $\begin{array}{l}\mathrm{Y}_{\mathrm{t}} \\
\left(\mathrm{MN} / \mathrm{m}^{3}\right)\end{array}$ & $\begin{array}{l}\text { Joint } \\
\text { condition }\end{array}$ & $\begin{array}{l}\mathrm{C}, \mathrm{s}_{\mathrm{t}} \\
(\mathrm{MPa})\end{array}$ & $\begin{array}{l}f \\
\left({ }^{\circ}\right)\end{array}$ & $\begin{array}{l}f_{r} \\
\left({ }^{\circ}\right)\end{array}$ & $\begin{array}{l}\mathrm{k}_{\mathrm{n}} \\
(\mathrm{MPa} / \mathrm{m})\end{array}$ & $\begin{array}{l}\mathrm{k}_{\mathrm{s}} \\
(\mathrm{MPa} / \mathrm{m})\end{array}$ & $\begin{array}{l}\mathrm{C}, \mathrm{s}_{\mathrm{t}} \\
(\mathrm{MPa})\end{array}$ & $\begin{array}{l}d \\
\left({ }^{\circ}\right)\end{array}$ & $\begin{array}{l}\mathrm{k}_{\mathrm{n}} \\
(\mathrm{MPa} / \mathrm{m})\end{array}$ & $\begin{array}{l}\mathrm{k}_{\mathrm{s}} \\
(\mathrm{MPa} / \mathrm{l}\end{array}$ \\
\hline Hard & & $1.0 \times 10^{5}$ & 0.2 & $2.7 \times 10^{-2}$ & Good & 0 & 50 & 35 & $2.33 \times 10^{5}$ & $0.96 \times 10^{5}$ & 0 & 33 & $2.33 \times 10^{5}$ & $0.96 \times 1$ \\
\hline $\begin{array}{l}\text { Slightly } \\
\text { weathered }\end{array}$ & 23.20 & $1.0 \times 10^{4}$ & 0.22 & $2.6 \times 10^{-2}$ & Fair & 0 & 40 & 32 & $2.33 \times 10^{4}$ & $0.96 \times 10^{4}$ & 0 & 27 & $2.33 \times 10^{4}$ & $0.96 \times 1$ \\
\hline $\begin{array}{l}\text { Moderately } \\
\text { weathered }\end{array}$ & & $1.0 \times 10^{3}$ & 0.25 & $2.5 \times 10^{-2}$ & Poor & 0 & 35 & 31.5 & $2.33 \times 10^{3}$ & $0.96 \times 10^{3}$ & 0 & 23 & $2.33 \times 10^{3}$ & $0.96 \times 1$ \\
\hline
\end{tabular}

$\mathrm{EI}=$ Wall bending stiffness, $\mathrm{E}_{\mathrm{r}}=$ Intact rock elastic modulus, $\mathrm{n}=$ Poisson's ratio, $\mathrm{Y}_{\mathrm{t}}=$ Unit weight of intact rock, $\mathrm{c}=$ Joint or interface cohesion, $\mathrm{s}_{\mathrm{t}}=\mathrm{J}$ Joint or interface tensile strength, $\mathrm{f}=$ Joint friction angle, $\mathrm{f}_{\mathrm{r}}=$ Joint residual friction angle, $\mathrm{d}=$ Interface friction angle, $\mathrm{k}_{\mathrm{n}}=$ Joint or interface normal stiffness, $\mathrm{k}_{\mathrm{s}}=\mathrm{J}$ oint or interface shear stiffness

To evaluate the properties of rock masses controlled by joints, the study employed a two dimensional Universal Distinct Element Code, UDEC (2004) that can allow for substantial displacements to be generated between the rock blocks. UDEC is a numerical modelling code used by geotechnical, civil and mining engineers in analysis, testing and design of engineering structures and materials. This code was developed to accommodate all kinds of geotechnical engineering projects where analyses of jointed or blocky systems are required, and can also be used for the advanced soil and rock analyses (Itasca, 2014). In this numerical simulation, the wall, struts and rocks were modelled as distinct elastic units due to the simplicity of the elastic model. The interfaces and joints between rock blocks and walls were simulated using Coulomb slip model, in which the contact loses strength and sliding occurs when the contact shear stress exceeds the contact shear strength.

To reflect a typical deep excavation size and wall height, the study used $68.8 \mathrm{~m}$ x $31.5 \mathrm{~m}$ as the model dimension while a $20.5 \mathrm{~m}$ deep soldier pile and timber lagging wall, which is the excavation wall, was used as shown in Figure 3. The width of excavation was taken to be $20 \mathrm{~m}$. Strut supported systems were adopted in line Peck's earth pressure that was used in comparison with the results of this study. To reflect typical excavation procedures in the field, eight excavation steps (Figure 4) were performed to obtain magnitude of earth pressure. Prior to conducting first stage of excavation, the first equilibrium level was achieved using the at-rest pressure coefficient and the boundary condition was roller for both the vertical and horizontal boundaries. After ensuring the first equilibrium condition, the displacements were reset to zero. The exaction wall was then installed to a depth of $20.5 \mathrm{~m}$. The first excavation was carried out to a depth $1.0 \mathrm{~m}$ and this was followed by the first strut installation at $0.5 \mathrm{~m}$ above the excavation line. There was additional excavation every $3 \mathrm{~m}$ after the first excavation in line with general excavation procedure, and this was followed by the installation of strut at every $3 \mathrm{~m}$ interval. Wall stabilization was secured after each excavation step and the final excavation was carried out up to $19.0 \mathrm{~m}$ as shown in Figure 5 .

Albeit the shape of general excavation wall has little influence on wall movement and earth pressure in the field if the wall bending stiffness is equivalent, numerical tests can have an ample impact on the results due to a stress concentration in modelling. However, it is hard to completely model the structural form of a typical wall using numerical study. As a way of addressing this issue, the wall used was transformed into a simple section that represent the equivalent wall bending stiffness (Figure 5 and Equation 4).

\section{$\mathrm{E}_{\mathrm{v}} \mathrm{I}_{\mathrm{b}} \mathrm{N}_{\mathrm{v}}+\mathrm{E}_{\mathrm{w}} \mathrm{I}_{\mathrm{w}} \mathrm{N}_{\mathrm{w}}=\mathrm{E}_{\mathrm{t}} \mathrm{I}_{\mathrm{t}}$}

Where $E_{p}=$ elastic modulus of the soldier pile, $E_{W}=$ elastic modulus of the timber lagging, $E_{t}=$ elastic modulus of the transformed section, $I_{p}=$ second moment of area for the soldier pile, $I_{w}=$ moment of inertia of the timber lagging, $I_{t}=$ moment of inertia for the transformed section, $N_{p}=$ number of soldier pile per unit metre and $N_{w}=$ unity.

\section{Impact Of Joint Inclinations}

The impact of joint inclinations on earth pressure magnitude and distribution in rock mass was investigated. To comprehensively study the influence of joint inclinations, the joint angles considered, ranged from $0^{\circ}$ to $90^{\circ}$ in the interval of $5^{\circ}$ and the results of the investigation are discussed below.

Figures 6 and 7 compare the apparent and total earth pressures for hard rock with different joint inclination angles, respectively. For joint inclinations between 0 and $40^{\circ}$ which induced no joint sliding, the induced earth pressures were quite small and much lesser than the Peck's empirical earth pressure for sand 
ground. The pressure increased slightly with increase of joint angles and the ratio of the total earth pressure values, which is the ratio of apparent earth pressure to Peck's earth pressure, increased from 0.01 to 0.07 . However, for joint angles around $60^{\circ}$, the apparent earth pressure increased and had the maximum value as a result of joint sliding that occurred when shear stress at the joints exceeded its strength. In this case, the apparent earth pressure values were higher than Peck's earth pressure at the upper part, though the earth pressure values reduced down the depth as result of increased confined pressure down the excavation. The ratio of the total earth pressure values, where joint sliding occurred (joint angles around $60^{\circ}$ ), ranged between 0.59 and 0.72 . After the maximum value, the apparent earth pressures decreased with joint inclination angle. For higher joint inclinations, the ratio of the total earth pressures between the apparent earth pressures induced from the numerical tests compared to Peck's earth pressure varied from 0.27 to 0.47 . The apparent earth pressures for joint inclinations between 85 and $90^{\circ}$ were very small and similar to those of $0-40^{\circ}$. These results clearly showed that joint inclination angles have significant effect on earth pressures most especially when rocks are in the state of joint sliding. The induced earth pressures became higher with increase of joint angles, reached highest value around joint inclination angle of $60^{\circ}$ (i.e between 55 and $60^{\circ}$ ), and it then became lowered with further increase of joint inclination angle.

Figures 8 and 9 compare the apparent and total earth pressures for slightly weathered rock with different joint inclination angles, respectively. The apparent earth pressures for the joint inclination angles, where no sliding was induced at the joint, were slightly higher than those of hard rock for the same joint angles but lower than the Peck's empirical earth pressure. The total earth pressure ratio for the numerical tests increased slightly from 0.11 to 0.56 for joint inclination angles. For joint angles around $60^{\circ}$, the induced apparent earth pressure increased with increase in joint inclination angle with the maximum value occurring between the joint inclination angles of $55^{\circ}$ and $60^{\circ}$. The earth pressures were fairly higher than those of hard rock with the same joint angles. Similar to hard rock, the apparent earth pressures were higher than Peck's earth pressure at the upper part, but decreased down the depth due to increase in confine pressure with depth. The total earth pressure ratios for these joint inclination angles ranged between 0.72 and 0.84 . For higher joint inclination angles, the total earth pressure ratio between the apparent earth pressures induced from the numerical tests and Peck's earth pressure ranged from 0.27 to 0.47 . The apparent earth pressures for joint inclination angles between 85 and $90^{\circ}$ were very small and similar to those of joint angles between 0 and $35^{\circ}$.

Figures 10 and 11 compare the apparent and total earth pressures for moderately weathered rock due to different joint inclination angles, respectively. The induced earth pressures increased with increase of joint angles form 0 to around $60^{\circ}$ and the apparent earth pressure then decreased beyond this angle. The ratio of the total earth pressures for these joint angles varied from 0.58 to 0.94 . The earth pressure values were substantially higher when compared to those of hard and slightly weathered rocks regardless of joint angles because of higher block deformation tendency in moderately weathered rock. These clearly indicated that earth pressure increased considerably as the rock deteriorated more, whereas the influence of joint inclinations decreased. This is evident from the results of the statistical analysis shown in Table 2 with an increase in p-value or a decrease in Fcal (calculated variance ratio) as the rock conditions became worsen. In order words, the impact of joint angles and joint sliding is more evident and statistically significant in hard rock than slightly and moderately weathered rock types.

Table 2: One way ANOVA showing the impact of joint inclination on earth pressure magnitude

\begin{tabular}{|lllllll|}
\hline Rock type & Source of Variation & Degree of freedom & Fcal & P-value & F crit & Remark \\
\hline Hard & Joint inclination angle & 1 & 48.06626 & $4.02 \mathrm{E}-08$ & 4.113165 & SS \\
\hline Slightly weathered & & 1 & 47.78044 & $4.28 \mathrm{E}-08$ & 4.113165 & SS \\
\hline \begin{tabular}{l} 
Moderately weathered \\
\cline { 1 - 7 }
\end{tabular} & & 1 & 46.9998 & $5.08 \mathrm{E}-08$ & 4.113165 & SS \\
\hline
\end{tabular}

$F c a l=$ calculated variance ratio, $F$ crit $=$ stipulated ratio of variance, $P$-value $=$ probability value,

SS = Statistically Significantly

\section{Conclusions}

The impact of different joint angles on earth pressure magnitude and distribution on the excavation wall installed in rock masses was investigated. Results clearly showed that joint angles and rock types have significant effect on the magnitude of earth pressure in rock masses.

The earth pressure increased with increasing joint inclinations and became highest around joint inclination angle of $60^{\circ}$ as a result joint sliding that occurred when the shear stress at the joints exceeded its strength.

As a result of higher tendency of block deformation in moderately weathered rock, the induced apparent earth pressures were substantially higher when compared with those of hard and slightly weathered rocks, but the impact of joint angles and joint sliding is more evident and statistically significant in hard rock than slightly and moderately weathered rock types.

The comparisons of the earth pressure in sand and rock ground showed that earth pressures in rock ground are substantially varied from those in sand ground. They are substantially higher in rock ground when the rock conditions are very poor but much lower than that of sand when rock is under good and fair conditions. Therefore, effects of rock and joint conditions and characteristics are very important when designing retaining structure for rock masses.

\section{Declarations}

\section{Acknowledgments}


This paper acknowledged the supports given by the Korea Research Foundation (2010-2015).

\section{References}

Bienniawski, Z.T. (1976). Rock mass classificn. in rock eng., John Wiley\& Sons, New York.

Bieniawski, Z.T. (1989). Engineering rock mass classification, Chichester, Willey, London.

Fu, J., Xie, J., Wang, S., Yang, J., Yang, F. and Pu, H. (2019). Cracking performance of an operational tunnel lining due to local construction defects, Int. jour. Of Geomech. 19: 1943-1956.

Gan, F., Ye, X., Yin, K., Li, M. and Bi, J. (2017). Analysis of stress characteristics and the engineering application of the self-balancing retaining wall, adavancces in mat. sci. and eng. 2017: 1-10.

Goodman, R. E. (1989). Introductn. to rock mech., Wiley \& Sons, Yew York.

Haahash, Y.M.A. and Whittle, A.J. (2002). Mech. of load transfer and arching for bra. Exc. in clay." Jou. of Geot. and Geoenv. Eng. 128: 187-197.

Hoek, E. and Brown, E.T. (1988). Underground exc. in rock, Instit. of Min. and Metallurg., London.

Hong, W.P. and Yoon, J. M. (1995). Jou. of Kor. Geot. Soc. 11: 63-77.

Itasca Consulting Group, Inc. (2014). Universal distinct element code. User's manual. Itasca Consulting Group, Inc., Minneapolis, Minn.

Jeon, S. and Lee, S. (2018). Track stability assessment for deep excavations in adjacent to urban railways, Jou. of the Korea academia-industrial cooperation soc. 19: 614-627.

Jeong, E.T. and Kim, S.G. (1997) Cas. Stud. of eart. press. distr. on exc. Wal. of multi-layrd. soil. Kor. Geot. Soc. '97 sprng. conf. 78-80.

Lambe, T.W. and Whitman, R.V. (1978). Soil mechanics, SI version, John Wiley \& Sons Inc., New York.

Lee, J.G. and Jeon, S.G. (1993). Eart. press. distr. on woodn. Wal. durg multi - layrd. soil. exc. Kor. Geot. Soc. 9: 59-68.

Lee, S.H. (2001). A stud. on the roc. pres. wedg. failur. dur. grou. exc., Engineering Geology Korean Geological Society 11: 1-11.

Lee, S.M. (2004). Urban Railway Almanac (2): Cut \& Cover Tunnel Seoul Subway Construction Headquarter 417-429.

Peck, R. B. (1969). Dep. Exc. \& Tunn. in Sof. Grou. " Proc,.of the 7th Intern. Conf. on Soil Mech. \& Found. Eng., Mexic., Stat.-of. Vol. 225-290.

Potts, D. M. and Fourie, A.B. (1986). A num. study of the effect of wal. def on earth pressures. Int. Journ of Num. Ana. Methods in Geomech $10: 383-405$.

Son, M. (2013). Eart. pres. on sup. Sys. in joint. roc. mas. Canadi. Geot.. Jou. 50: 493-502.

Son, M. and Park, J. (2014). Physic. mod. tes. \& numeric. simulat. of exc. wal. in joint. roc. mas. Canadi. Geot. Jou. 51: 554-569.

Son, M. and Adedokun, S. (2014a) "Earth Pressures against the Excavation Wall in a Jointed Rock Mass" Eight International Symposium on Geotechnical Aspects of Underground Construction in Soft Ground, International Society of Soil Mechanics and Geotechnical Engineering, Seoul, South Korea. pp. 449-452. doi: 10.1201/b17240-84.

Son, M and Adedokun, S. (2014b) Effec. of joint on eart. press. agai. the excav. wall in joint. roc. mas. Jou. of the Korean Soc. of Civ. Engr. $34: 505-513$. Son, M. and Adedokun, S. (2015) Effec. of join. inclinati. angl. on eart. press. agai. the sup. Sys. in joint. roc. mas. KSCE Jou. of Civ. Eng. 20: $1259-1266$. Son, M. and Adedokun, S. (2016) Effec. of roc. mas. conditi. on eart. press. agains. an exc. wal. in roc mas: Numericl. investigatn. Jou. of Kor. Geot. Soc. 33: 83-95.

Son, M and Adedokun, S. (2017). Eart. press. on ret. str. in layr. \& joint. roc. mas., Jou. of Civ. Eng. 21: 1147-1153.

Son, M. and Yoon, C. (2011). Charact. of the earth pressure magn. and distrib. in a joint. rockmass Jou. of the Korean Soc. of Civil Eng., $31: 203-212$.

Terzaghi, K. (1934). Large retaining-wall tests: I-Pressure of dry sand. Engineering News Record 111: 136-140.

Terzaghi, K. (1936). A fundamental fallacy in earth pressure computations, Boston Society of Civil Engineers. Journal 23: 71-88.

Tschebotarioff, G.P. (1973). Found., Ret. \& Eart. Struct.. Second Edn., MG.

UDEC .(2004). Unive. Distin. Elem. Cod., User. Manu., Minneapol., Minnesot., US.

Wong, I.H., Poh, T.Y. and Chuah, H.L. (1997). Perfor. of exc. for depressed expressway in Singapore. Jou. of Geot. and Geoenv. Eng. 123: 617-625. 
Worden, F.T. and Achmus, M. (2013). Num. model. of 3 - dim. active earth pressure actg on rigid walls. Comp. and Geotec. 51: 83-90.

Yoo, C.S. (2001). Beh. of brac. \& anchr. wal. in soil. overlyg. roc. Jour. Geotec. and Geoenvir. Engrg. 127: 225-233.

Zeng, S., Wang, S., Sun, B. and Liu, Q. (2018). Propagation characteristics of blasting stress waves in layered and jointed rock caverns, Geot. and Geol. Eng., 36: $1559-1573$

\section{Figures}

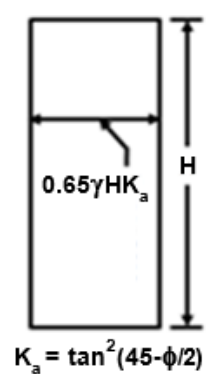

Sand

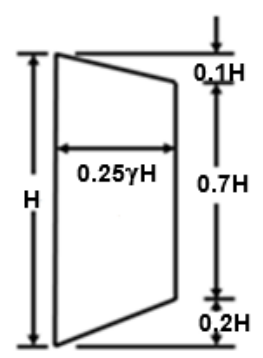

Sand

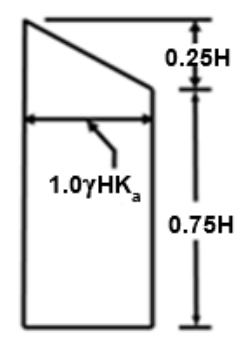

$K_{\mathbf{n}}=1-\left(4 \mathrm{~S}_{\mu} / \gamma \mathrm{H}\right)$

Soft to medium clay

a) Apparent earth pressure (Peck, 1969)

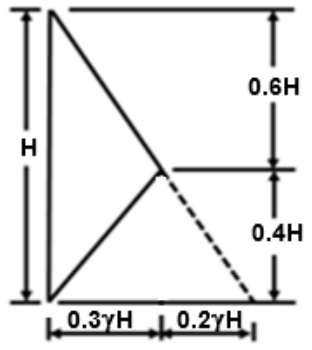

Temporary support

in stiff clay

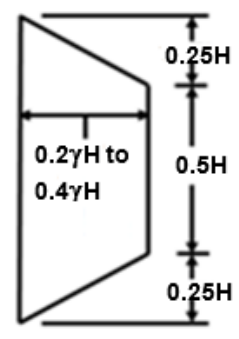

Stiff fissured clay

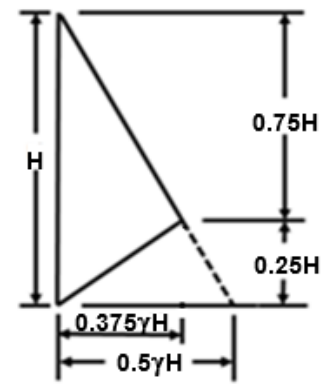

Permanent support in medium clay

b) Apparent earth pressure (Tschebotarioff, 1973)

Figure 1

Apparent earth pressure envelopes proposed for soil grounds 

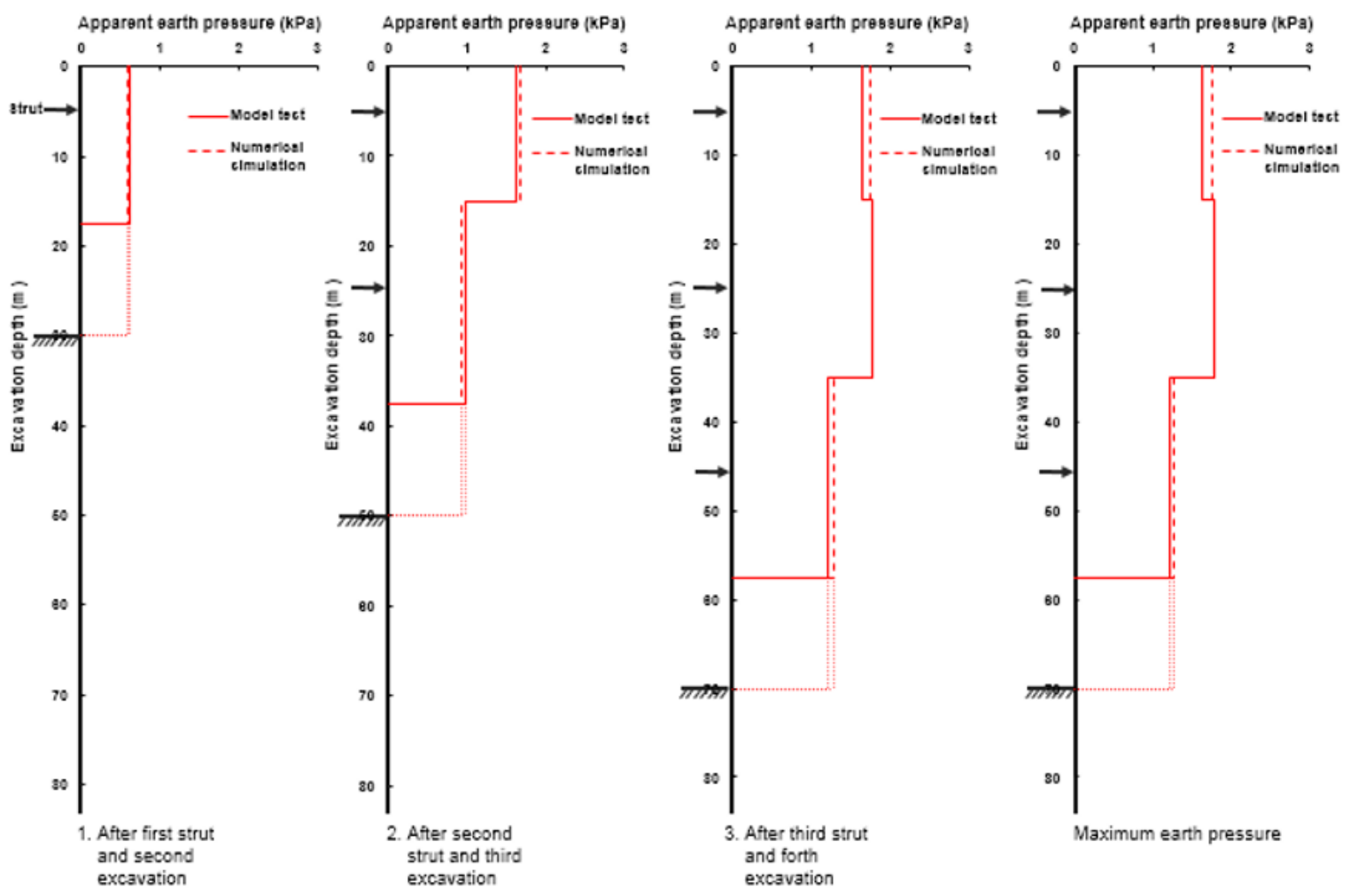

Figure 2

Result of the verification of the numerical simulation with physical model test (Son and Park, 2014)

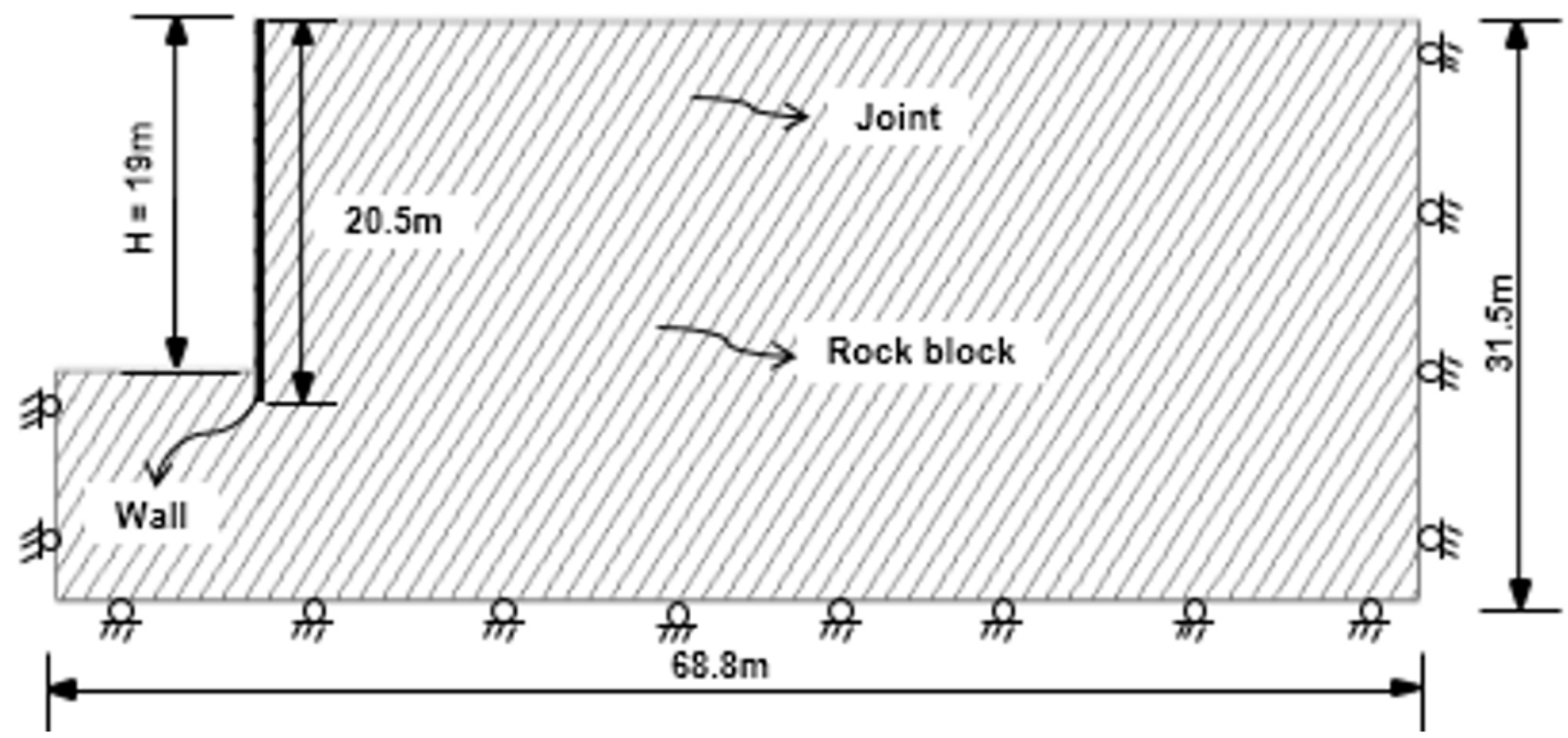

Figure 3

Model used for numerical analysis (an example of joint inclination angle of $60^{\circ}$ ) 

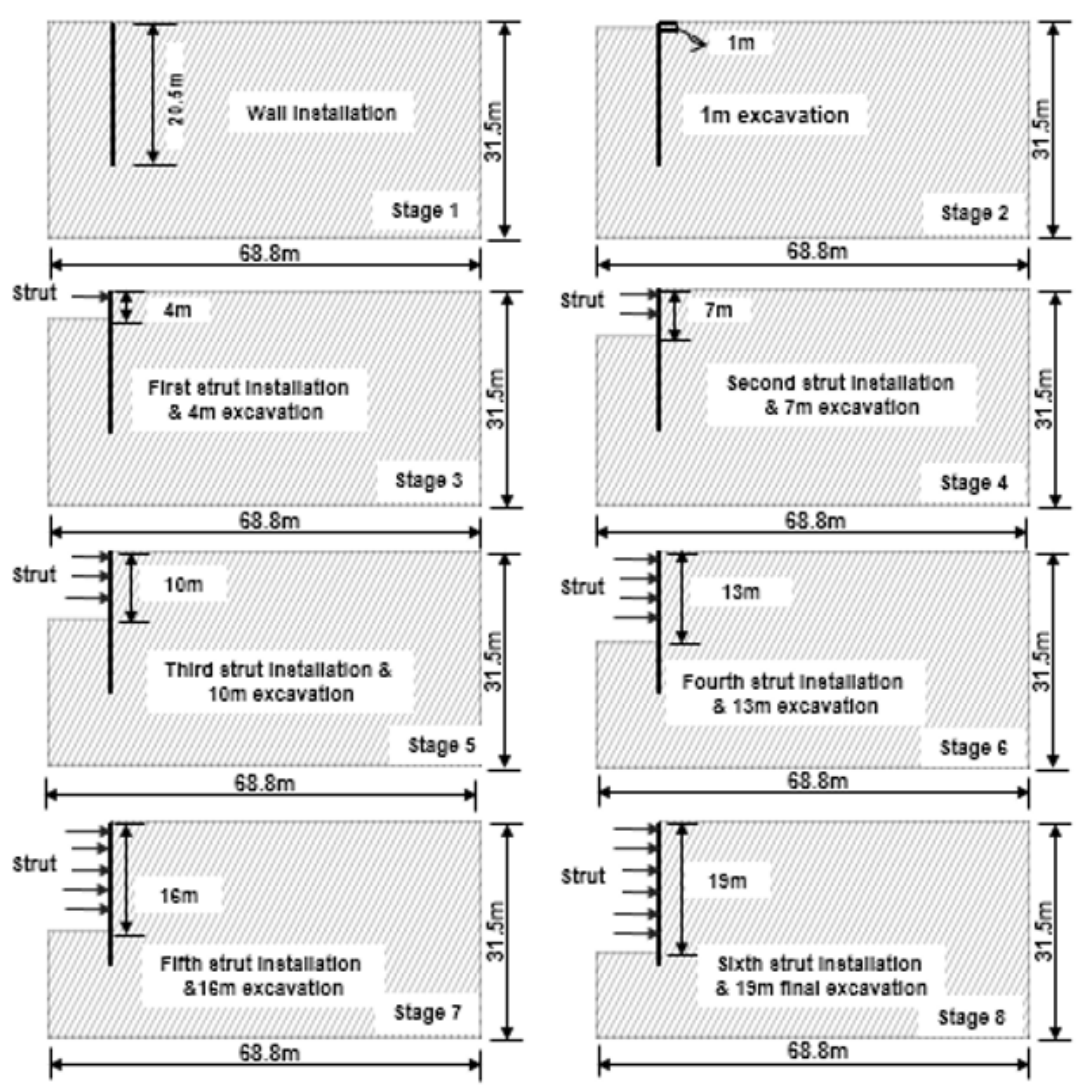

Figure 4

Sequential excavation steps in numerical simulation
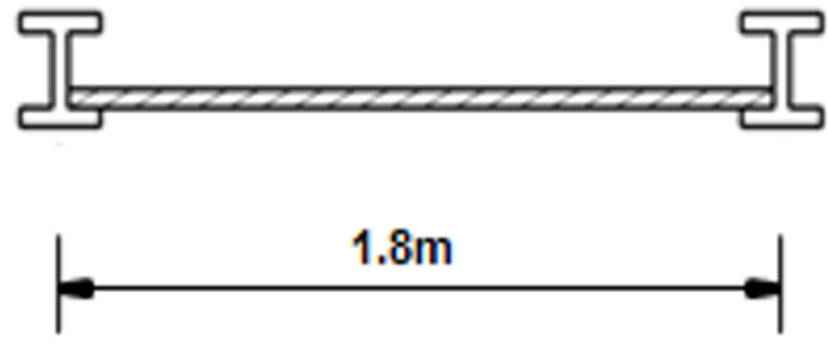

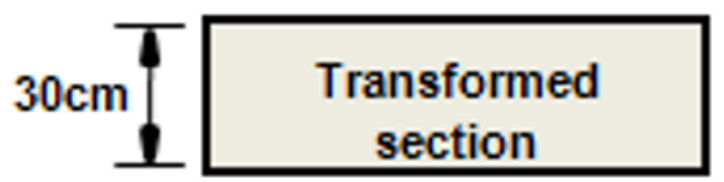

$1 \mathrm{~m}$

Figure 5

Changed section with equivalent flexural stiffness 


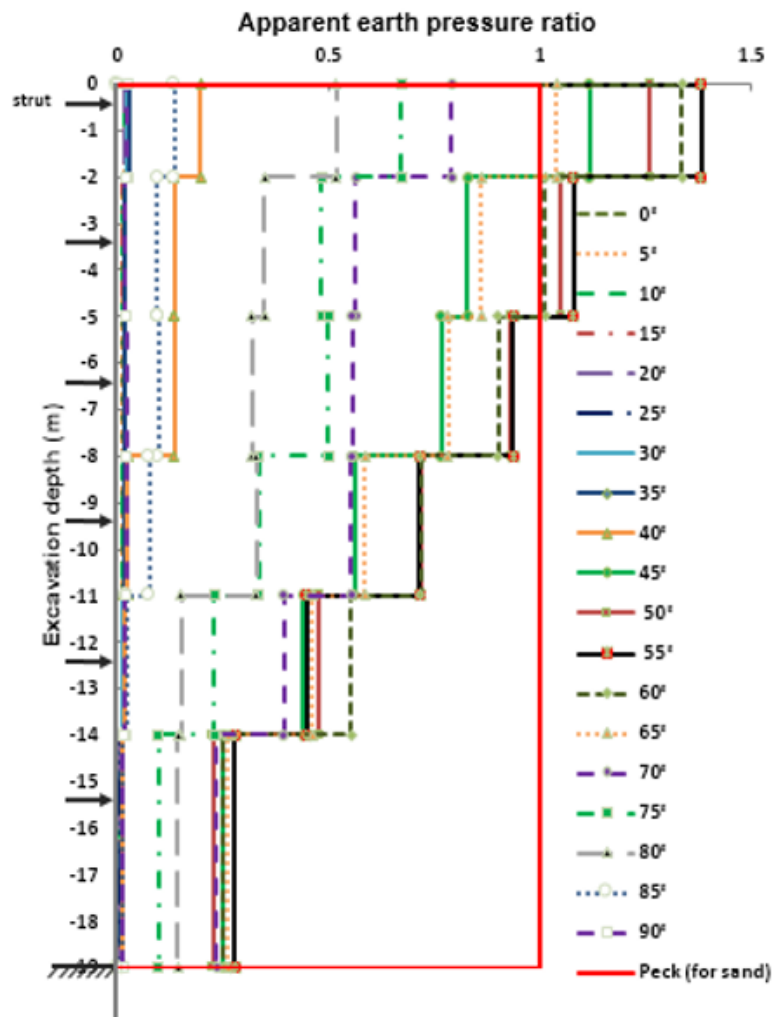

Figure 6

Apparent earth pressures for hard rock under varying joint inclination angles

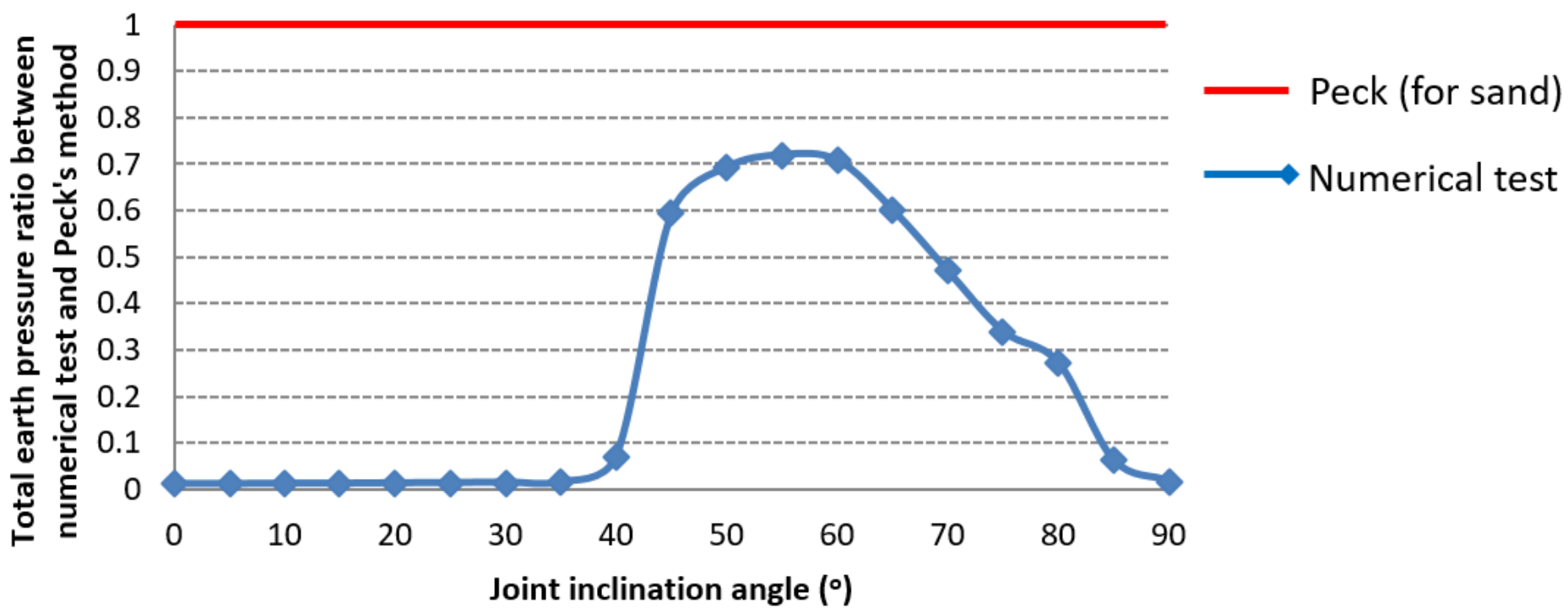

Figure 7

Total earth pressures for hard rock under varying joint inclination angles 


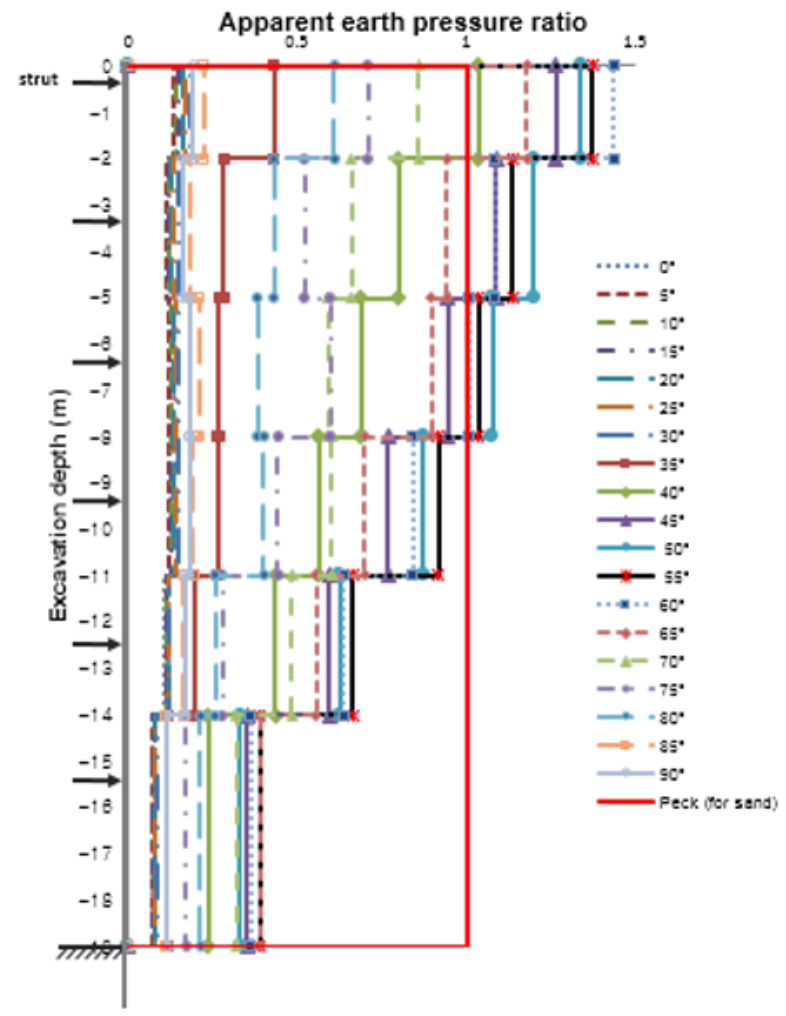

Figure 8

Apparent earth pressures for slightly weathered rock under varying joint angles

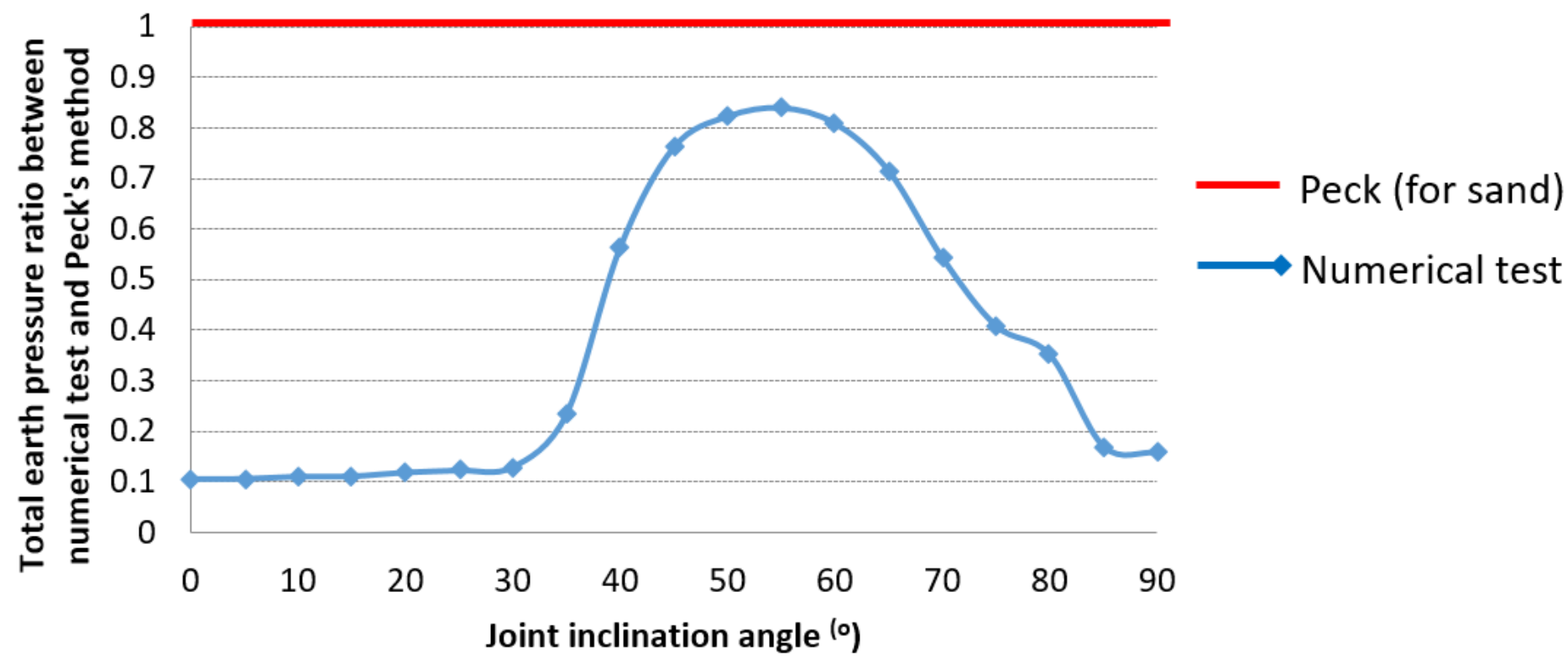

Figure 9

Total earth pressures for slightly weathered rock under varying joint inclination angles 


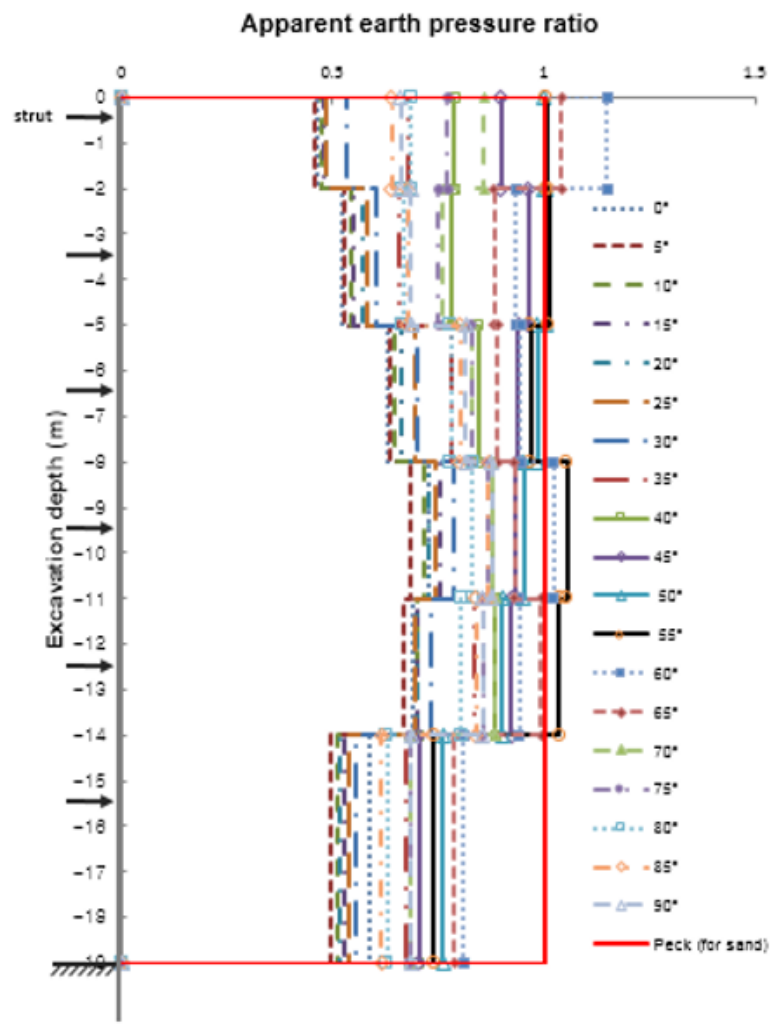

Figure 10

Apparent earth pressures for moderately weathered rock under varying joint angles

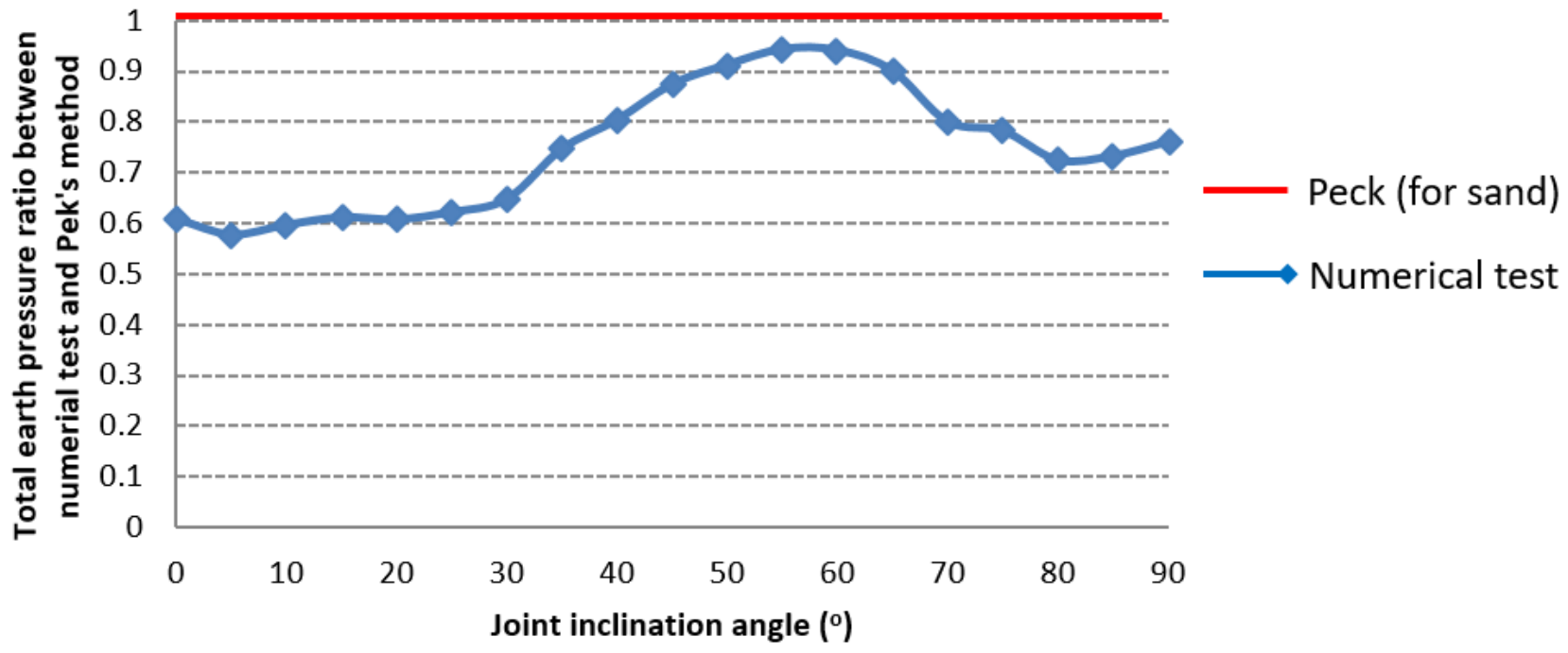

Figure 11

Total earth pressures for moderately weathered rock under varying joint angles 